\title{
Cooling causes changes in the distribution of lipoprotein lipase and milk fat globule membrane proteins between the skim milk and cream phase
}

\author{
J. A. Dickow, L. B. Larsen, M. Hammershøj, and L. Wiking ${ }^{1}$ \\ Department of Food Science, Faculty of Agricultural Sciences, Aarhus University, DK-8830 Tjele, Denmark
}

\begin{abstract}
Lipoprotein lipase (LPL) activity and free fatty acid levels were studied in freshly milked, uncooled milk from individual Danish Holstein or Jersey cows, or after storage for up to $24 \mathrm{~h}$ at either a cooling temperature $\left(4^{\circ} \mathrm{C}\right)$ or at the milking temperature $\left(31^{\circ} \mathrm{C}\right)$. Upon cooling for up to $24 \mathrm{~h}$, LPL activity increased in the cream phase, whereas the activity in the skim milk was steady, as observed for Jersey cows, or increased, as seen for the Holsteins. Storage at $31^{\circ} \mathrm{C}$ decreased the LPL activity in both the cream phase and the skim milk phase. The increase in free fatty acid levels was found to depend on LPL activity, incubation temperature, substrate availability, and incubation time. Furthermore, the migration of milk proteins between the skim milk phase and the cream phase upon cooling of milk from Jersey cows or from Danish Holstein cows was studied using proteomic methods involving 2-dimensional gel electrophoresis and mass spectrometry. Proteins associated with the milk fat globules were isolated from all milk fractions and analyzed. Major changes in the distributions of proteins between the skim milk phase and the cream phase were observed after cooling at $4^{\circ} \mathrm{C}$ for $4 \mathrm{~h}$, where a total of 29 proteins between the 2 breeds was found to change their association with the milk fat globule membrane (MFGM) significantly. Among these, the MFGM proteins adipophilin, fatty acid-binding protein, and lactadherin, as well as the non-MFGM proteins $\beta$-casein, lactoferrin, and heat shock protein-71, were identified. Adipophilin, lactadherin, and lactoferrin were quantitatively more associated with the MFGM upon cold storage at $4^{\circ} \mathrm{C}$, whereas $\beta$-casein, fatty acid-binding protein, and heat shock protein-71 were found to be less associated with the MFGM upon cold storage.
\end{abstract}

Key words: cooling, lipoprotein lipase, milk fat globule membrane, temperature

Received June 21, 2010.

Accepted October 28, 2010.

${ }^{1}$ Corresponding author: lars.wiking@agrsci.dk

\section{INTRODUCTION}

Cooling milk to $4^{\circ} \mathrm{C}$ soon after milking inhibits spore outgrowth. Furthermore, cooling before pumping stabilizes the milk fat against the formation of FFA (Wiking et al., 2005). The FFA formation is caused by lipoprotein lipase (LPL; EC 3.1.1.34) activity. In fresh milk, the majority, approximately $90 \%$, of LPL activity is associated with the casein fraction (McSweeney, 2004). However, cooling causes LPL activity to increase in the milk fat globule membrane (MFGM) fraction (Hohe et al., 1985). The MFGM is derived from the plasma membranes of the secretory cells and is similar to other epithelial membranes composed of cholesterol, phospholipids, proteins, and glycoproteins. It is presumably organized according to the fluid mosaic model by Singer and Nicolson (1972) and is not a static biophysical system, but a highly dynamic organization with a heterogeneous distribution of phospholipids and glycoproteins (Evers et al., 2008; Lopez et al., 2010). The association of several proteins to the MFGM is reported to change when fresh milk is cooled (Hohe et al., 1985; Steffensen et al., 2004; Wiking et al., 2005). The 8 quantitatively dominant MFGM proteins found in bovine milk are adipophilin (ADPH), butyrophilin, cluster of differentiation 36 (also known as PAS 4), fatty acid-binding protein (FABP), lactadherin (also known as PAS 6/7), mucin 1, mucin 15, and xanthine oxidase (XOD) (Fong and Norris, 2009). Of these, XOD has been reported not only to increase its overall activity in full milk upon cold storage, but also to change the distribution of activity between the skim milk phase and cream phase so that the XOD activity increases more in the skim milk phase than in the cream phase (Bhavadasan and Ganguli, 1980). Proteomic methods have been applied for the characterization of major and minor proteins in skim milk and MFGM and have been reviewed (O'Donnell et al., 2004; Reinhardt and Lippolis, 2006; Fong et al., 2007).

Lipoprotein lipase activities also are reported to change in the cream phase upon cooling of fresh milk (Sundheim and Bengtsson-Olivecrona, 1985). Lipoprotein lipase is an enzyme participating in the lipoprotein metabolism in blood and tissue, where it catalyzes the 
hydrolysis of ester bonds of triacylglycerols, resulting in the release of FFA. This hydrolysis is unwanted in drinking milk as elevated levels of short-chain FFA in particular may result in off flavors. In contrast, in blue cheese production, for example, the LPL activity releasing FFA contributes to the characteristic flavor of such cheese types by further oxidation to methylketones (Cinbas and Kilic, 2006). Lipoprotein lipase is activated by apolipoprotein C-II (Nilsson-Ehle et al., 1980). The active form of LPL is a dimer of identical 50-kDa subunits (Iverius and Ostlundlindqvist, 1976; Humbert et al., 1997), and the dissociation of these subunits into monomers or the assembly into higher oligomers results in the inactivation of LPL (Osborne et al., 1985). In milk, LPL is assumed to associate with the MFGM upon cooling (Wang and Randolph, 1978). The LPL activity in the cream fraction is influenced both by milking intervals and stage of lactation (i.e., a greater lipase activity in the cream phase has been observed in milk from short milking intervals and with advancing stage of lactation; Ahrné and Bjorck, 1985). Regardless of milking intervals and stage of lactation, a positive correlation between LPL association with the cream fraction and the actual lipolysis in milk has been demonstrated (Sundheim and Bengtsson-Olivecrona, 1985). The association of LPL to MFGM seems to be optimal after 3 to $5 \mathrm{~h}$ of cooling, where the presence of heparin during the cooling process enhances this association (Sundheim and Bengtsson-Olivecrona, 1985). The negatively charged heparin stimulates the release of LPL from the caseins, thereby increasing the amount of free LPL in milk serum during the cooling process (Sundheim and Bengtsson-Olivecrona, 1985). The binding mechanism of LPL to MFGM is not fully understood. Lipoprotein lipase is known to bind to the negatively charged heparan sulfate on the surface of cell walls (Sehayek et al., 1995) and to bind lipoproteins thereby bridging the two (Olivecrona and Olivecrona, 1995) to assist the cellular uptake of lipoproteins (Casaroli-Marano et al., 1998). Lipoprotein lipase is rather heat-sensitive and can be completely inactivated by pasteurization for $10 \mathrm{~s}$ at $85^{\circ} \mathrm{C}$ (Driessen, 1989).

Despite earlier investigations of the association of LPL to the MFGM as a function of cooling temperature and time, no studies have included the proper control sample: milk stored at milking temperature over the same period. Therefore, only the effect of time at cold storage has previously been shown. It is relevant to study the effect of both temperature and time on LPL and LPL-derived activity in milk fractions. For example, in relation to the manufacture of cheeses where rancidity is desired, such as blue cheese, feta, and kefalotyri, it is important to investigate the effect of the cooling and heating history of milk on LPL activity and distri- bution in milk fractions and the effect on FFA formation. Also, in relation to purification of LPL or MFGM proteins, it is important to understand the changes induced by cooling on LPL activity and, at the molecular level, in the distribution of MFGM proteins. The risk of losing LPL activity may increase by storing milk at $31^{\circ} \mathrm{C}$, because purified LPL stored at $37^{\circ} \mathrm{C}$ is known to be very unstable (Iverius and Ostlundlindqvist, 1976). The present study compared cooled and uncooled milk during $24 \mathrm{~h}$ from 2 different dairy breeds, Jersey and Danish Holstein. Our hypothesis was that cooling milk changes the distribution or association of LPL and its activity, as well as a range of other MFGM proteins between the skim milk phase and the cream phase. The aim of the study was to investigate the effect of cooling on the composition of proteins associated with MFGM using proteomic methods, and furthermore to study the effect of storage time and temperature on LPL activity in milk fractions obtained from 2 dairy breeds.

\section{MATERIALS AND METHODS}

\section{Cows, Milk Samples, and Storage}

Four Danish Holsteins and 4 Jersey cows (89 to 241 DIM, SCC $<130,000$ cells $/ \mathrm{mL}$ ) from the resident herd at the Danish Cattle Research Center (Tjele, Denmark) were used in the experiments. The cows were fed a TMR ad libitum, supplemented with concentrate according to standard practice, and milked by a Delaval robot (Tumba, Sweden). Four liters of milk from each milking per individual cow was collected by pumping from the robot's collection tank to the sampling bottles. Milk fat content was analyzed on a MilkoScan FT2 (Foss, Hillerød, Denmark) and expressed as percentage by weight. The temperature of the milk at the end of milking was $31.5 \pm 0.5^{\circ} \mathrm{C}$. The milk from each cow was divided into 2 sets: one set of milk was incubated at $31^{\circ} \mathrm{C}$ after the addition of $0.03 \% \mathrm{NaN}_{3}$, whereas the other set was cooled in ice water and held at $4^{\circ} \mathrm{C}$ until analysis. Samples were collected at 0 and $24 \mathrm{~h}$ from the milk incubated at $31^{\circ} \mathrm{C}$, and at 4 and $24 \mathrm{~h}$ from the milk incubated at $4^{\circ} \mathrm{C}$ for further processing and analyses.

\section{Separation of Milk into Skim Milk and Cream}

Of each milk sample, $26 \mathrm{~mL}$ was separated into cream and skim milk by centrifugation (Optima L-80 XP, Beckman Coulter, Fullerton, CA). The milk incubated at $4^{\circ} \mathrm{C}$ was centrifuged at $8,430 \times g$ for $11 \mathrm{~min}$. The milk incubated at $31^{\circ} \mathrm{C}$ was separated by centrifugation at $20,275 \times g$ for $15 \mathrm{~min}$. Due to a less efficient separation of cream at higher temperatures, a larger centrifugal force was required at $31^{\circ} \mathrm{C}$ to obtain a skim milk with a 
resulting fat content of $0.47 \%(\mathrm{SE}=0.15 \%)$. Aliquots of skim milk and cream fractions were stored at $-20^{\circ} \mathrm{C}$ until further analyses.

\section{Preparation of MFGM}

The cream fractions from the previous separations were washed twice with 10 and $5 \mathrm{~mL}$ of $5 \mathrm{mM}$ phosphate buffer ( $\mathrm{pH}$ 7.4), respectively, and centrifuged for $11 \mathrm{~min}$ and $25 \mathrm{~min}$, respectively, at $1,440 \times \mathrm{g}$ at room temperature. The MFGM with peripherally associated proteins was separated from washed cream by pelleting for 10 min at 17,900 $\times g$ in an Eppendorf (Hørsholm, Denmark) $5417 \mathrm{R}$ centrifuge at $40^{\circ} \mathrm{C}$.

\section{Analysis of LPL Activity in Milk}

The LPL activity was measured by applying a method developed for lipase activity analysis in clinical and purified systems as described by Olivecrona and Olivecrona (2000). The assay was optimized with regard to milk concentration and incubation time to ensure a linear response. The addition of $10 \mu \mathrm{L}$ of milk or $10 \mathrm{mg}$ of cream diluted 1:1 ( $\mathrm{vol} / \mathrm{vol}$ or wt/vol, respectively) with $5 \mathrm{~m} M$ Na-deoxycholate, $0.1 \mathrm{~m} M$ SDS, and $20 \mathrm{mM}$ Tris $(\mathrm{pH} 8.5)$, and incubation for $20 \mathrm{~min}$, was found to be suitable. The possible influence of $\mathrm{NaN}_{3}$ addition to the $31^{\circ} \mathrm{C}$ samples was investigated and found not to affect the lipase activity measurements.

\section{Analysis of FFA in Milk}

Milk samples were pasteurized $\left(71^{\circ} \mathrm{C}, 15 \mathrm{~s}\right)$ after incubation at either 4 or $31^{\circ} \mathrm{C}$ to inactivate LPL. After cooling with ice water, the milk samples were stored at $-20^{\circ} \mathrm{C}$ until later analysis. The FFA were analyzed according to the Bureau of Dairy Industries method (International Dairy Federation, 1991) and expressed as millimoles of FFA/100 g of fat.

\section{Two-Dimensional Gel Electrophoresis}

The samples containing proteins extracted from MFGM were centrifuged for $20 \mathrm{~min}$ at $14,000 \times g$ and $4^{\circ} \mathrm{C}$. Fat and excess liquid were removed, and the obtained protein pellets were resuspended in $200 \mu \mathrm{L}$ of $10 \mathrm{~m} M$ Na-citrate (pH 5.0). A volume of $50 \mu \mathrm{L}$ of each suspension was added to $150 \mu \mathrm{L}$ of lysis buffer $(6 \mathrm{M}$ urea, $2 M$ thiourea, $1.5 \%$ (wt/vol) pharmalyte, $0.8 \%$ (wt/vol) 3-[(3-cholamidopropyl) dimethylammonio]1-propanesulfonate, $1 \%(\mathrm{wt} / \mathrm{vol})$ dithioerythritol in water) and stored at $-20^{\circ} \mathrm{C}$ until analysis. Samples were diluted 25 times in $\mathrm{H}_{2} \mathrm{O}$, and protein concentration was measured by the Bradford method (Bio-Rad,
Hercules, CA). After incubation for $2 \mathrm{~h}$ at room temperature, a volume corresponding to $160 \mu \mathrm{g}$ of protein from the aliquots of each sample was combined and further diluted in a rehydration buffer to a final volume of $200 \mu \mathrm{L}$. The rehydration buffer was similar to the lysis buffer, only with Pharmalyte $(5 \mu \mathrm{L} / \mathrm{mL})$ instead of $1 \%$ dithioerythritol. The first dimension of protein separation was carried out on 11-cm immobilized $\mathrm{pH}$ gradient (IPG) strips ( $\mathrm{pH} 4-7$ or $3-10)$, and 8 to $16 \%$ Criterion gels (Bio-Rad) were used for the second dimension. Running conditions for the 2-dimensional gel electrophoresis gels were essentially as described earlier (Lametsch and Bendixen, 2001). Analytical gels were stained with Flamingo pink (Bio-Rad) and scanned using a Molecular Imager FX (Bio-Rad). Images were analyzed with PDQuest (Bio-Rad). Gels for spot identification were stained with colloidal Coomassie Blue R-250 (Kang et al., 2002).

In gel digestion for peptide mass fingerprinting, desalting and concentration of protein spots, identification of MFGM proteins by matrix-assisted laser desorption ionization-time-of-flight mass spectrometry (MALDITOF MS), and image analysis was performed as described previously (Larsen et al., 2010).

\section{Statistical Analysis}

All data were subjected to statistical analysis by the generalized linear models procedure of SAS (version 9.2, SAS Institute Inc., Cary, NC). The following model was used for the data analysis of lipase activity and FFA:

$$
\mathrm{Y}_{\mathrm{ijk}}=\mu+\mathrm{T}_{\mathrm{i}}+\mathrm{H}_{\mathrm{j}}+\varepsilon_{\mathrm{ijk}},
$$

where $Y_{\mathrm{ijk}}=$ dependent variable; $\mu=$ overall mean; $\mathrm{T}_{\mathrm{i}}$ $=$ the effect of temperature $\left(\mathrm{i}=4,31^{\circ} \mathrm{C}\right) ; \mathrm{H}_{\mathrm{j}}=$ the effect of storage time $(\mathrm{j}=0,4,24 \mathrm{~h}) ; \varepsilon_{\mathrm{ijk}}=$ residual error; $P<0.05$ was used as significance threshold, and the Jersey and Holsteins cows were analyzed separately.

The following model was used for the MFGM protein data:

$$
\mathrm{Y}_{\mathrm{ijk}}=\mu+\mathrm{T}_{\mathrm{i}}+\mathrm{B}_{\mathrm{j}}+\left(\mathrm{T} \times \mathrm{B}_{\mathrm{ij}}\right)+\varepsilon_{\mathrm{ijk}},
$$

where $Y_{\mathrm{ijk}}=$ dependent variable; $\mu=$ overall mean; $\mathrm{T}_{\mathrm{i}}$ $=$ the effect of treatment $\left(\mathrm{i}=0 \mathrm{~h}, 31^{\circ} \mathrm{C} ; 4 \mathrm{~h}, 4^{\circ} \mathrm{C} ; 24 \mathrm{~h}\right.$, $\left.31^{\circ} \mathrm{C} ; 24 \mathrm{~h}, 4^{\circ} \mathrm{C}\right) ; \mathrm{B}_{\mathrm{j}}=$ the effect of breed $(\mathrm{j}=$ Jersey, Holstein); $\mathrm{T} \times \mathrm{B}_{\mathrm{ij}}=$ interactions between the variables of treatment and breed; $\varepsilon_{\mathrm{ijk}}=$ residual error; and $P<$ 0.05 was used as significance threshold.

When a significant treatment effect was found, a 2 -tailed paired $t$-test was used with a $95 \%$ confidence interval between individual treatments to disclose whether cooling or time was responsible for the signifi- 

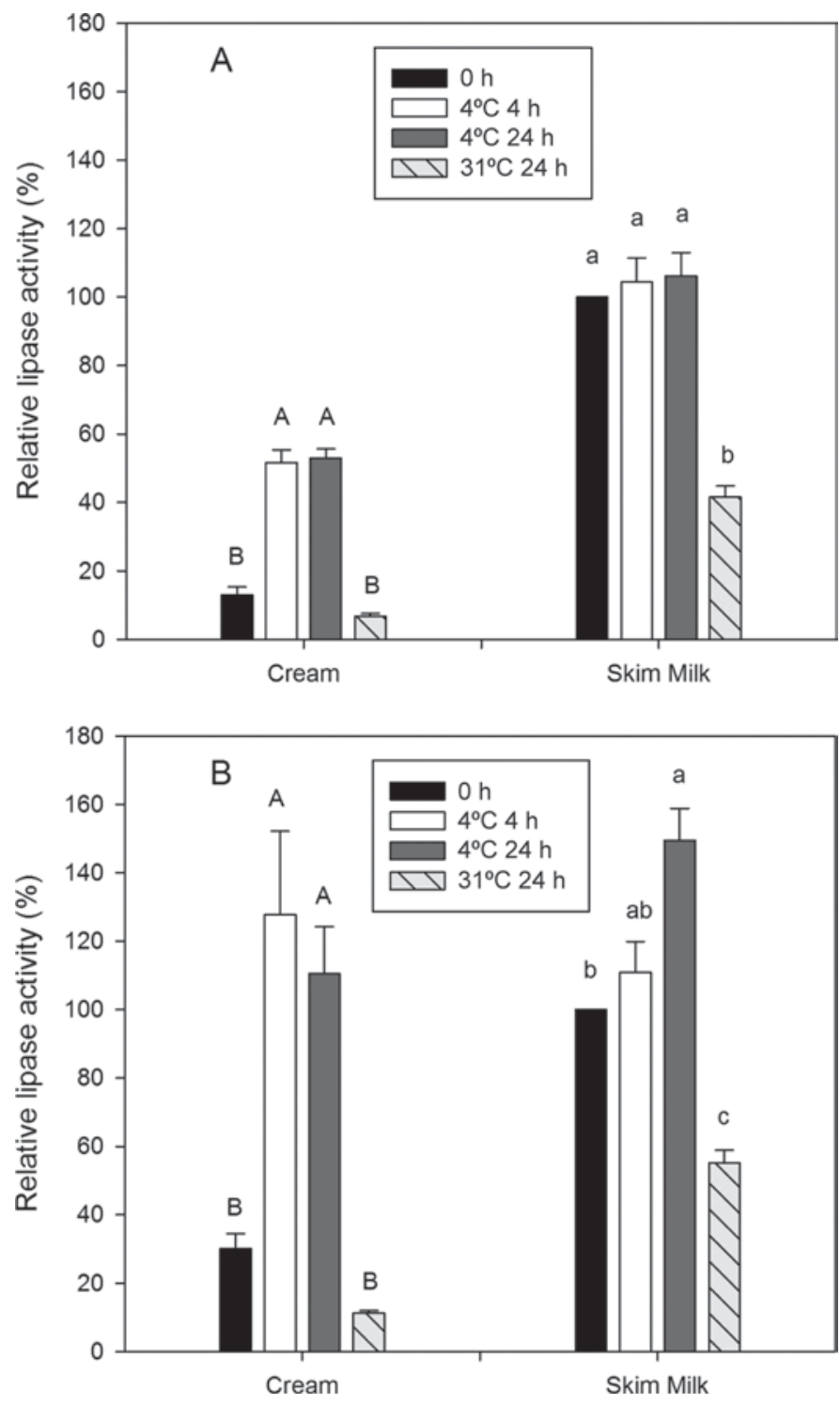

Figure 1. Lipoprotein lipase activity in milk stored at $4^{\circ} \mathrm{C}$ or $31^{\circ} \mathrm{C}$ for 4 to $24 \mathrm{~h}$ followed by separation into cream and skim milk ( $+\mathrm{SE}, \mathrm{n}$ $=4)$. Activities are given relative to that of the fresh skim milk for (A) Jersey milk and (B) Danish Holstein milk. Different letters indicate significantly different values at $P<0.05$.

cant difference. Student's t-test was carried out using Minitab 14 (Minitab Inc., State College, PA).

\section{RESULTS AND DISCUSSION}

\section{Lipase Activity and FFA Formation}

The LPL activity in the cream phase increased $(P$ $<0.05)$ for both breeds as a function of cooling, as illustrated in Figure 1. Lipase activities in cream phases did not differ between milk cooled for $4 \mathrm{~h}$ and milk cooled for $24 \mathrm{~h}$, indicating that the association of LPL to the MFGM does not change further during storage time beyond $4 \mathrm{~h}$ at $4^{\circ} \mathrm{C}$. This is in accordance with the findings of Sundheim and Bengtsson-Olivecrona (1985). During cold storage, the LPL activity in the skim milk phase from Jersey cows remained at a steady level as a function of time (Figure 1a), and increased approximately $50 \%$ in the Danish Holstein milk that was stored for $24 \mathrm{~h}$ (Figure 1b). The observed increase was significant in all 4 cows. The milk stored at $31^{\circ} \mathrm{C}$ showed a decrease in LPL activity of 45 to $65 \%$ in both phases for both breeds. The decrease in LPL activity was only significant $(P<0.05)$ in the skim milk phases. The ratio of LPL activity between skim milk phases and cream phases remained unchanged at $31^{\circ} \mathrm{C}$. Isothermic storage did not cause a change in LPL association with the cream phase relative to its presence in the skim milk phase, only a degradation of the LPL protein itself or inhibition of its activity. It is possible that protein oxidation occurs in raw milk at $31^{\circ} \mathrm{C}$, and the decrease in LPL activity could be a consequence of this factor. Purified LPL has been shown to be rapidly inactivated at similar temperatures (Olivecrona and Bengtsson, 1984).

The results of FFA release in the milk are shown in Figure 2. The FFA concentrations significantly increased over time in Holstein milk stored at $31^{\circ} \mathrm{C}$ (Figure 2B), and no other changes were found to be significant. The correlation between FFA concentrations in the milk and the residual LPL activity in cream after storage was not entirely straightforward. An earlier study reported that increased LPL activity associated with the cream fraction was correlated to greater FFA concentrations among individual cows (Ahrné and Bjorck, 1985). Storage at $31^{\circ} \mathrm{C}$ is close to the temperature optimum for LPL activity, which is $37^{\circ} \mathrm{C}$ (Walstra and Jenness, 1984), and almost all milk lipids are in a liquid state; therefore, increased formation of FFA could be expected under these conditions. In contrast, $4^{\circ} \mathrm{C}$ is far from the optimal enzyme temperature, and furthermore, between 28 and $45 \%$ of the milk lipids are solid at this temperature (Wiking et al., 2005). However, the present study demonstrates that cooling increases the association of LPL activity with the cream phase, and this factor contributes to the FFA concentration after $24 \mathrm{~h}$ cold storage being comparable to that of the milk incubated under near-optimal conditions $\left(31^{\circ} \mathrm{C}\right)$ for LPL activity. The crystallization of the milk fat as a consequence of cooling causes volume changes in the core of the milk fat globule, which is likely to deform the membrane. This deformation of the membrane renders conformational changes that perhaps attract LPL. In a system with isolated milk fat globules, it is shown that these become more susceptible to lipolysis from purified LPL when precooled (Sundheim and Bengtsson-Olivecrona, 

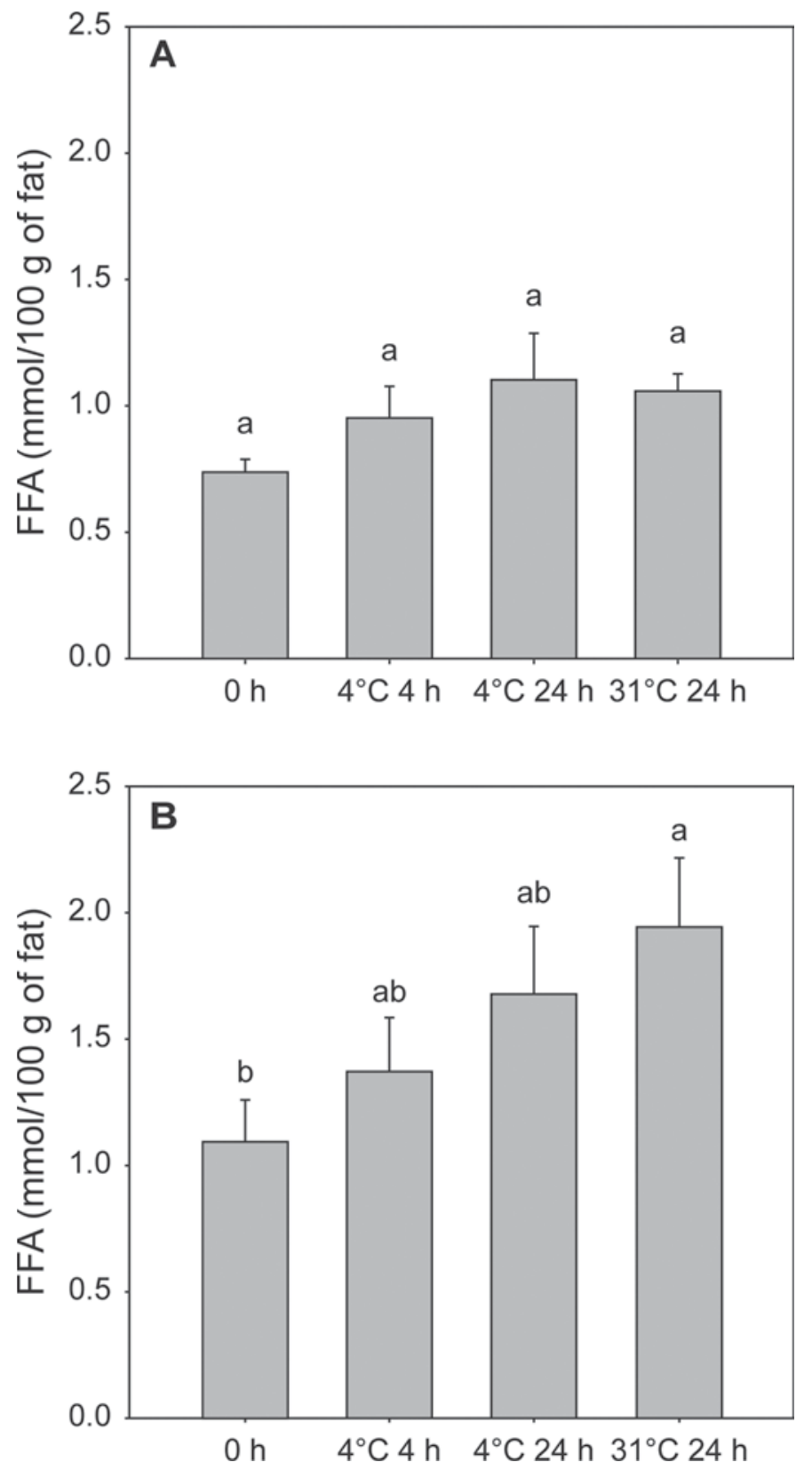

Figure 2. Concentration of FFA in (A) Jersey milk and (B) Danish Holstein milk stored at $4^{\circ} \mathrm{C}$ or at $31^{\circ} \mathrm{C}$ for up to $24 \mathrm{~h}(+\mathrm{SE}, \mathrm{n}=4)$. Different letters indicate significantly different values at $P<0.05$.

1987). These factors contribute to the explanation of why FFA levels are similarly increased in milk stored at $31^{\circ} \mathrm{C}$ and in milk stored at $4^{\circ} \mathrm{C}$, together with the fact that LPL is thermolabile (Walstra and Jenness, 1984).

This study investigated the importance of substrate availability, LPL localization in the milk phases for the formation of FFA, as well as LPL activity. The lipase action in the milk phases changed upon cooling, and an increasing concentration of FFA was observed in milk stored at $31^{\circ} \mathrm{C}$ (significant only for Danish Holstein milk), whereas residual lipase activity decreased $(P<$ 0.05) in milk stored at $31^{\circ} \mathrm{C}$ in both the skim milk and the cream phases. Furthermore, substrate availability was critical for the production of FFA by LPL, and cooling to $4^{\circ} \mathrm{C}$ decreased $(P<0.05)$ the amount of liquid milk fat in the cream phase (Wiking et al., 2005). Taken together, we conclude that LPL activity in milk cannot be investigated by analysis of the FFA concentrations alone. The outcome reflects the combination of the LPL activity, temperature, and substrate availability. Activating and inhibiting factors have been shown to influence the attachment of LPL to the MFGM, as reviewed by Deeth (2006); however, these factors are assumed not to change as an effect of cooling and to be part of the explanation for the observed migration of LPL to the MFGM. Furthermore, other conformational changes in the MFGM (e.g., the migration of proteins other than LPL) between the skim milk and the cream phases can be speculated to contribute to a weakening of MFGM resistance against LPL association. Enzymatic measurements have been used to characterize this change in protein composition (Evers, 2004b); however, measuring the changed association of a range of components could be a more valuable tool in the evaluation of MFGM changes.

\section{Changes in the Distributions of MFGM Proteins}

Initially, the separation of milk proteins on a $\mathrm{pH} 3$ to 10 IPG strip was investigated and compared with the separation obtained by using a $\mathrm{pH} 4$ to 7 strip. The separation obtained by the $\mathrm{pH} 4$ to 7 strip was much improved (results not shown). Furthermore, the presence of LPL was checked in the $\mathrm{pH} 3$ to 10 2-dimensional gel with the aim of identification by MALDITOF MS peptide mass fingerprinting, but no visible spots were present in the relevant region (isoelectric point, pI, of 8-9 and molecular mass around 50,000 Da; result not shown). It was therefore concluded that the LPL amounts were too low for detection in the 2-dimensional gels by the used staining. In retrospect, lipase is present in milk in concentrations of only 1 to 2 $\mathrm{mg} / \mathrm{L}$ (Fox and Kelly, 2006), and as estimated from the activity measurements, this concentration is not higher in the cream phase. A crude extraction of MFGM proteins from cream does not yield any enrichment of LPL; hence, the application of $160 \mu \mathrm{g}$ of MFGM proteins to a 2 -dimensional gel is not enough to visualize LPL on the gel. Other studies of the bovine MFGM proteome have not reported the discovery of LPL (Reinhardt and Lippolis, 2006; Fong et al., 2007). As the majority of milk proteins have $\mathrm{pI}$ in the range of 4 to 7 , it was decided to use this $\mathrm{pH}$ range for the subsequent quantitative 
proteomic study of the effect of cooling on the protein distribution in the MFGM fraction.

Statistical analysis of the relative spot volumes (spot volume for a particular spot relative to the total spot volumes for each gel) of the MFGM proteins obtained from the 2-dimensional gels with a $\mathrm{pH}$ range of 4 to 7 left a total of 73 spots that differed significantly $(P$ $<0.05)$ as a function of either breed or treatment, or both breed and treatment. This study aimed at the 37 spots that differed upon temperature or time treatment. Four spots were omitted due to very low relative spot volumes. The remaining 33 spots are listed in Table 1, and their positions on the 2-dimensional gels are illustrated for a Jersey milk sample as an example in Figure 3A. Table 1 lists the relative spot volumes and the responses to cooling or to incubation at milking temperature of these protein spots. Figure 3 shows the 2-dimensional gels of MFGM proteins from 1 Jersey milk sample representing milk that was (A) fresh, (B) stored for $4 \mathrm{~h}$ at $4^{\circ} \mathrm{C},(\mathrm{C})$ stored for $24 \mathrm{~h}$ at $31^{\circ} \mathrm{C}$, or (D) stored for $24 \mathrm{~h}$ at $4^{\circ} \mathrm{C}$. Of the 33 spots listed in Table 1 that change in either breed in response to treatment, 29 spots from either breed represented proteins that were found to change their distribution as a result of cooling at $4^{\circ} \mathrm{C}$ for $4 \mathrm{~h}$ (Table 1 , Cooling $\mathrm{A} \rightarrow \mathrm{B}$ ), whereas 4 spots were found to change their association with the MFGM fraction in response to milk storage time at milking temperature at $31^{\circ} \mathrm{C}$ for $24 \mathrm{~h}$ (Table 1 , Time $\mathrm{A} \rightarrow \mathrm{C}$ ). Comparison of Figures 3A and 3C confirms these minor changes. Among the 29 spots that changed in either breed in response to cooling at $4^{\circ} \mathrm{C}$ for $4 \mathrm{~h}$ (Figure $3 \mathrm{~A}$ to B), 15 spots represented proteins that were found to increase by 61 to $535 \%$, whereas 14 represented proteins decreasing by 42 to $93 \%$ in the MFGM fraction in response to the cooling treatment. It is clearly visible in the representative 2-dimensional gels that spot 106 decreases, whereas the train of spots 1902, 4909, 4908, 4907, 4906, 6901, and 6501 increases in the MFGM fraction by cooling for $4 \mathrm{~h}$ (Figure $3 \mathrm{~A}$ and $\mathrm{B}$ ). Storage for $24 \mathrm{~h}$ at $4^{\circ} \mathrm{C}$ (Figure 3D) showed a protein composition of MFGM-associated proteins ratio similar to that of Figure 3B $\left(4 \mathrm{~h} \mathrm{at} 4^{\circ} \mathrm{C}\right)$. No spots were found to associate significantly more with the MFGM of 1 breed while significantly associating less with the MFGM of the other breed as a function of treatment, but in many cases, a significant change in spot volume in 1 breed (see Table 1) was accompanied by a nonsignificant change in the other breed (data not shown). The phospholipid composition of fat globule membranes from Jersey and Holstein cows is different (Graves et al., 2007); thus, in further studies, it may be of interest to investigate if interactions between protein and phospholipids are responsible for the different MFGM protein association among breeds.
The major spots listed in Table 1 were excised for identification by peptide mass fingerprint using MALDI MS, and this led to the identification of 6 of the most abundant of these proteins. These identifications are listed in Table 2. Spots 106 and 201 were both identified as $\beta$-casein, which corresponds to previous identifications at these positions (Wedholm et al., 2008). This shows that the association of $\beta$-casein to the MFGM is reduced upon cooling of fresh milk. $\beta$-Casein is furthermore known to migrate from the casein micelles to the serum phase upon cooling (Davies and Law, 1983).

The large cluster of spots numbered 1902, 4906 to 4909, and 6901 was previously identified as lactoferrin (Wedholm et al., 2008). This identification was confirmed in this study for spot 1902 being part of this train of spots. Lactoferrin was observed to associate more strongly with the MFGM upon milk cooling. This association was observed to be significant for Jersey milk (Table 1) with a volume increase of $285 \%$, and with Holstein milk showing similar tendencies with 50$100 \%$ increases in lactoferrin spot volumes from fresh to cooled milk (results not shown). According to the measured mean relative spot volumes (Table 1), more lactoferrin was in general associated with the MFGM after $24 \mathrm{~h}$ of cold storage compared with $4 \mathrm{~h}$. In contrast, storage at $31^{\circ} \mathrm{C}$ did not significantly change the amount of lactoferrin associated to the MFGM compared with the fresh milk. The presence of lactoferrin as a train of spots at pI values from 4.9 to 5.7 is in contradiction to its theoretical pI value of 8.7 (calculation based on the sequence of the mature protein using SwissProt, accession number P24627, AA 20-708), and is thought to reflect different post-translational modifications of lactoferrin, and has been observed earlier (Wedholm et al., 2008). The fact that the train of spots migrates at around $80 \mathrm{kDa}$ indicates that the spots represent an intact protein and not fragments of lactoferrin. Bovine lactoferrin possesses at least 9 potential phosphorylation sites (Hatomi et al., 2000) and 5 potential glycosylation sites (Pierce et al., 1991). The composition of the glycosylations of bovine lactoferrin has previously been shown to vary with stage of lactation, with an average carbohydrate content of the purified protein of $11.2 \%$ (Spik et al., 1988). The observed pI values below the theoretical value could be a consequence of glycosylation and potential phosphorylation, and it is possible that the observed spots reflect a subpopulation of the total lactoferrin in the milk.

Spots 6101 and 9201 were both identified as FABP, a protein that exists in many different isoforms (Schroeder et al., 1998); however, its function in milk is unknown (Mather, 2000). Both spots were less associated with the MFGM upon cooling $(P<0.05)$ in Jersey milk and showed the same tendency in Holstein milk. As FABP 
Table 1. Spots in the milk fat globule membrane fraction identified by 2-dimensional gel electrophoresis to change significantly in response to milk storage at milking temperature $\left(31^{\circ} \mathrm{C}\right)$ or cooling $\left(4^{\circ} \mathrm{C}\right)$ for up to $24 \mathrm{~h}$

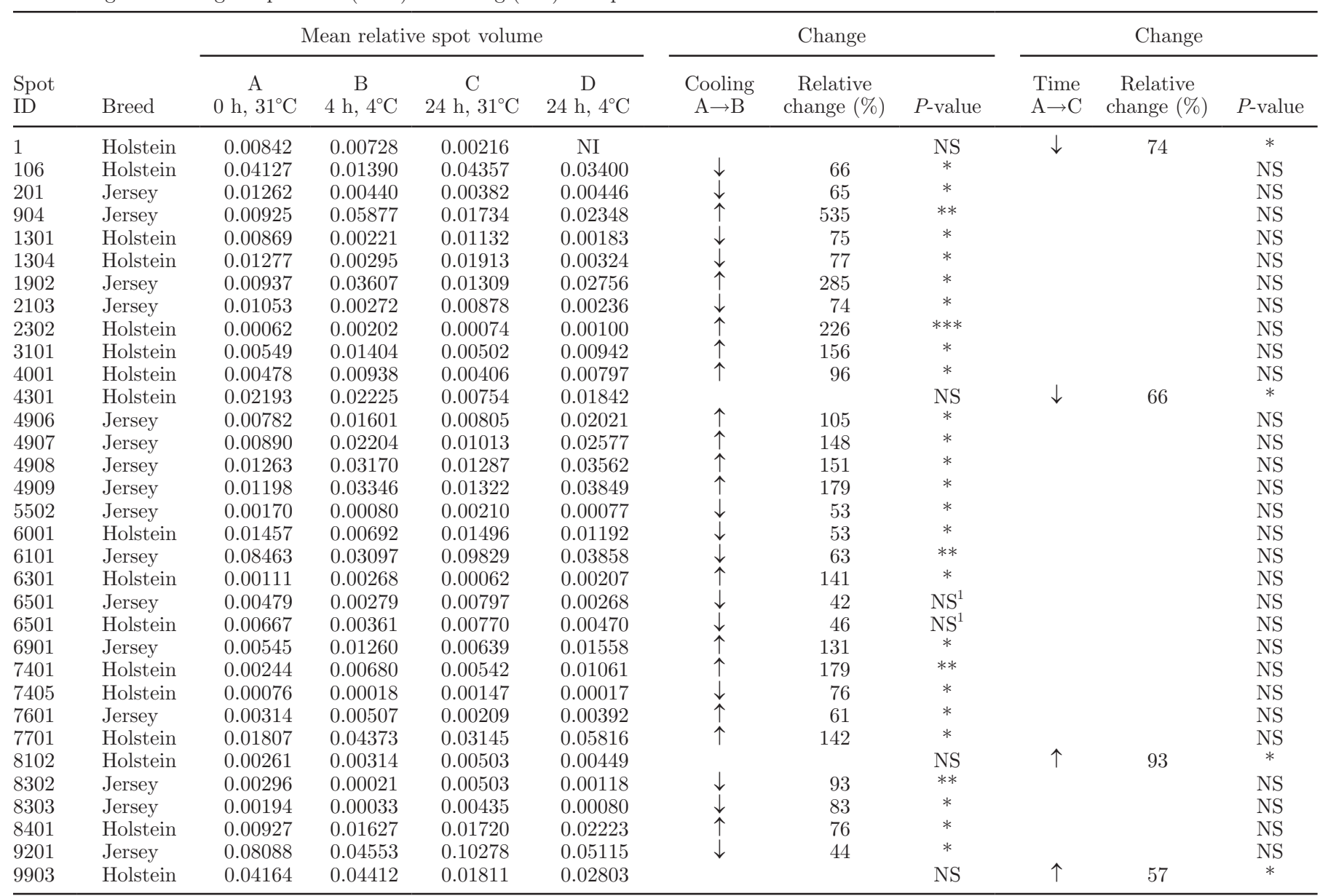

${ }^{1}$ Significant difference observed for both breeds between temperatures at $24 \mathrm{~h}, \mathrm{C} \rightarrow \mathrm{D}\left(24 \mathrm{~h}, 31^{\circ} \mathrm{C} \rightarrow 24 \mathrm{~h}, 4^{\circ} \mathrm{C}\right)$. NI $=$ not identified. ${ }^{* * *} P<0.001 ;{ }^{* *} P<0.01 ;{ }^{*} P<0.05$.

is a protein peripherally attached to the MFGM with no membrane-spanning domain (Mather, 2000), it appeared likely that structural changes of the membrane surface (e.g., the hardening of the fat globules upon cooling or the changed association of other proteins to the MFGM) changed the amount of FABP bound to the MFGM. Fatty acid-binding protein has been reported to associate to CD36 (Spitsberg et al., 1995); however, CD36 was not identified in this study and its association with the MFGM upon cooling of milk could not be investigated.

The 2 MFGM-associated proteins, ADPH and lactadherin, were found to change $(P<0.05)$ their association with the MFGM upon cooling in Holstein milk. Both proteins were more associated with the MFGM upon cooling. Adipophilin and lactadherin have similar MW and would comigrate in a 1-dimensional SDS-PAGE. Theoretically, they can be separated from each other by 2-dimensional gel electrophoresis (Vanderghem et al.,
2008) in that ADPH focuses as 2 isoelectric variants at pI 7.5 and 7.8 (Heid et al., 1996), whereas lactadherin has a theoretical pI of 7.0 as calculated from the mature AA sequence (Hvarregaard et al., 1996). However, in this study, focused on pI 4 to 7 strips, ADPH focused at a lower pI than lactadherin. Therefore, the quantified ADPH spot may only be 1 isoelectric variant of ADPH. Lactadherin migrates as a characteristic double band due to 2 glycosylation variants (Hvarregaard et al., 1996), and this double band was found not only in spot 8401, but also in several spots at slightly higher pI values. These spots did not change upon cooling and were not excised for identification by MALDI-TOF. Adipophilin is known to attach to lipid droplets and contains tightly bound fatty acids (Vanderghem et al., 2008). Lactadherin is a multifunctional glycoprotein known to bind to $\alpha_{\mathrm{V}} \beta_{5}$-integrins via an Arg-Gly-Asp (RGD) sequence in an epidermal growth factor-like domain and bind to phosphatidylserine-containing membranes via a 
A

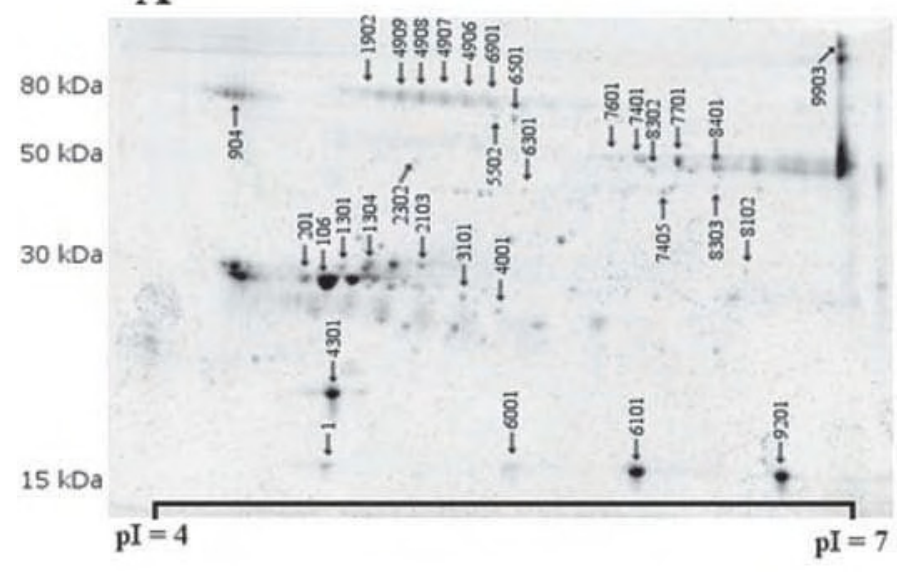

C

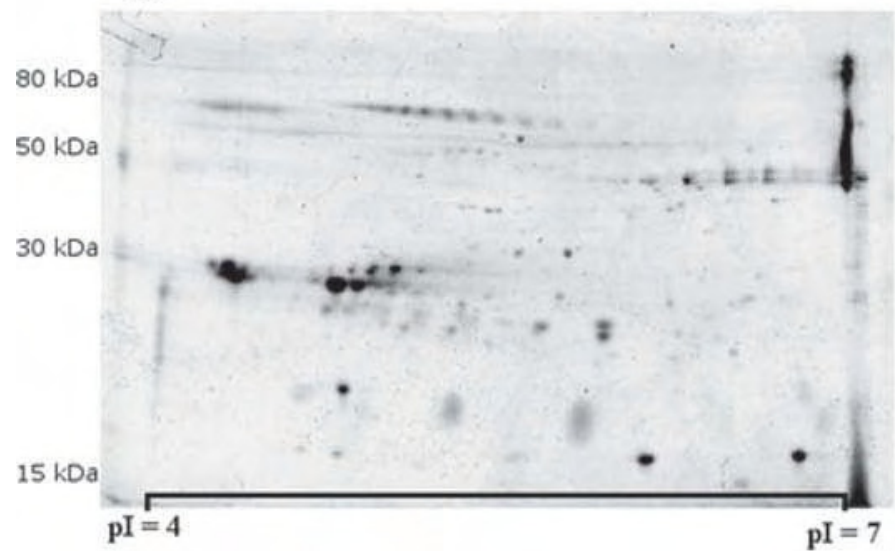

B

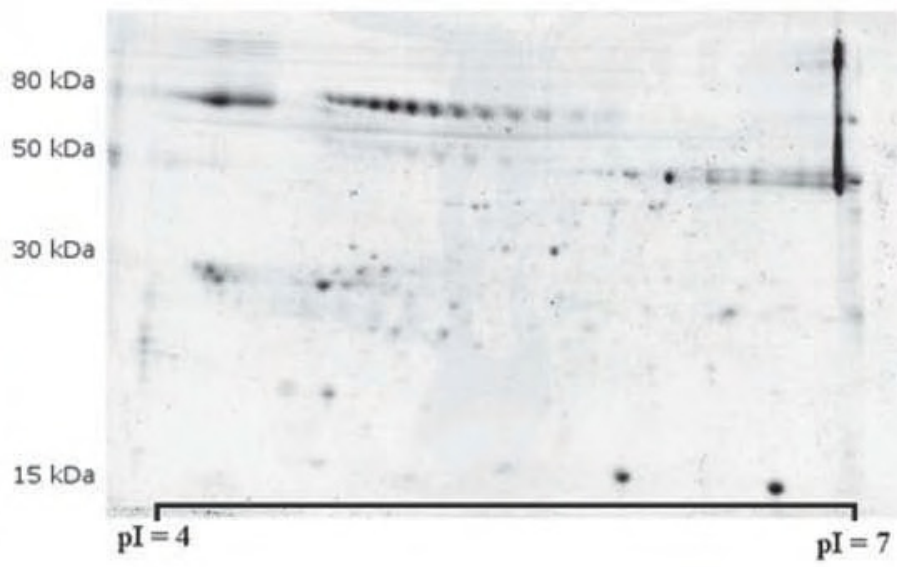

D

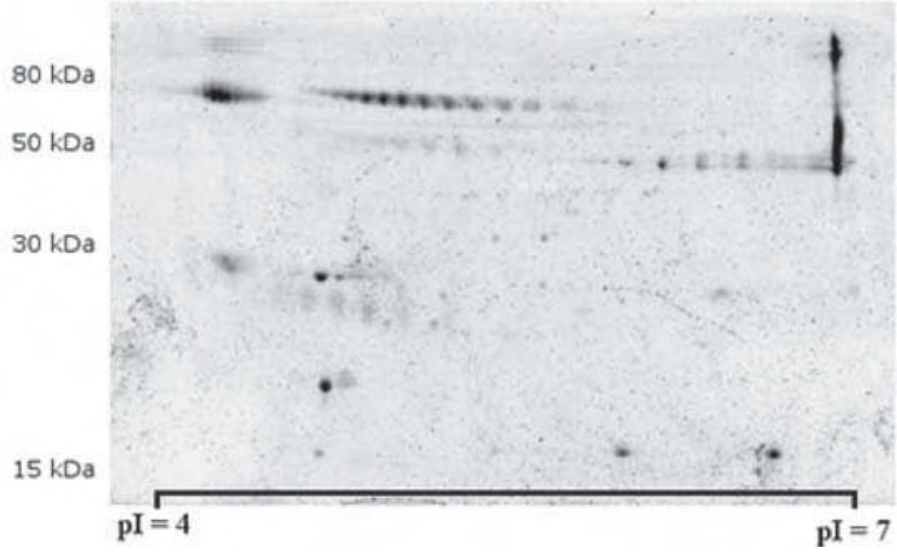

Figure 3. Two-dimensional gel electrophoresis gels of milk fat globule membrane fraction-associated proteins from Jersey milk subjected to 4 different time and temperature $\left(\mathrm{h} /{ }^{\circ} \mathrm{C}\right)$ treatments. Gel A: 0/31, gel B: 4/4, gel C: 24/31, and gel D: 24/4. Spots identified to change significantly $(P<0.05)$ upon either treatment are marked by their identification number on gel $\mathrm{A}$. $\mathrm{pI}=$ isoelectric point.

C2-like domain homologous to blood clotting factors V and VIII (Andersen et al., 1997). These binding properties make lactadherin function as a bridging molecule between apoptotic cells and macrophages signaling for the engulfment of the apoptotic cell (Hvarregaard et al., 1996; Andersen et al., 1997, 2000), as well as connecting sperm cells to zona pellucida (Ensslin and Shur, 2003; Copland et al., 2009). Human lactadherin has been shown to inhibit rotavirus infections (Newburg et al., 1998; Kvistgaard et al., 2004); however, bovine lactadherin appears not to possess this function (Kvistgaard et al., 2004).

Our study demonstrated that both ADPH and lactadherin have increased association with the MFGM upon cooling of fresh milk. This is useful information when designing purification schemes of these proteins from fresh milk; for example, for functional studies. It is recommended to cool the milk if purifying from the cream phase but to keep the milk at $31^{\circ} \mathrm{C}$ when using the skim milk as starting material.
A member of the heat shock protein family, HSP-71, was identified in spot 6501 to be less associated with the MFGM upon cooling of milk (Table 2). This diminished association was statistically significant $(P<0.05)$ in both Jersey and Holstein milks after $24 \mathrm{~h}$ of cooling. Heat shock proteins stimulate protein translocation across membranes (Chirico et al., 1988; Alder et al., 1990), but to our knowledge, it is not known whether HSP-71 stimulates any translocation across the MFGM or if its presence merely reflects the mammary epithelial cell membrane as origin of the MFGM.

Apart from the identified proteins, many spots significantly changed their spot volume on the 2-dimensional gels (Table 1), indicating that many proteins change their association with the MFGM upon cooling. Neither XOD nor LPL was found on the 2-dimensional gels due to their pI values of 7.7 for XOD (Berglund et al., 1996) and 8.5 for LPL (Senda et al., 1987), respectively, both being beyond the $\mathrm{pH}$ range for the IPG strips ( $\mathrm{pH} 4-7$ ) used in this study. The IPG strips of $\mathrm{pH} 4$ to 7 were 
Table 2. Proteins from milk fat globule membrane fraction identified by matrix-assisted laser desorption ionization-time-of-flight mass spectrometry of spots after 2-dimensional gel electrophoresis

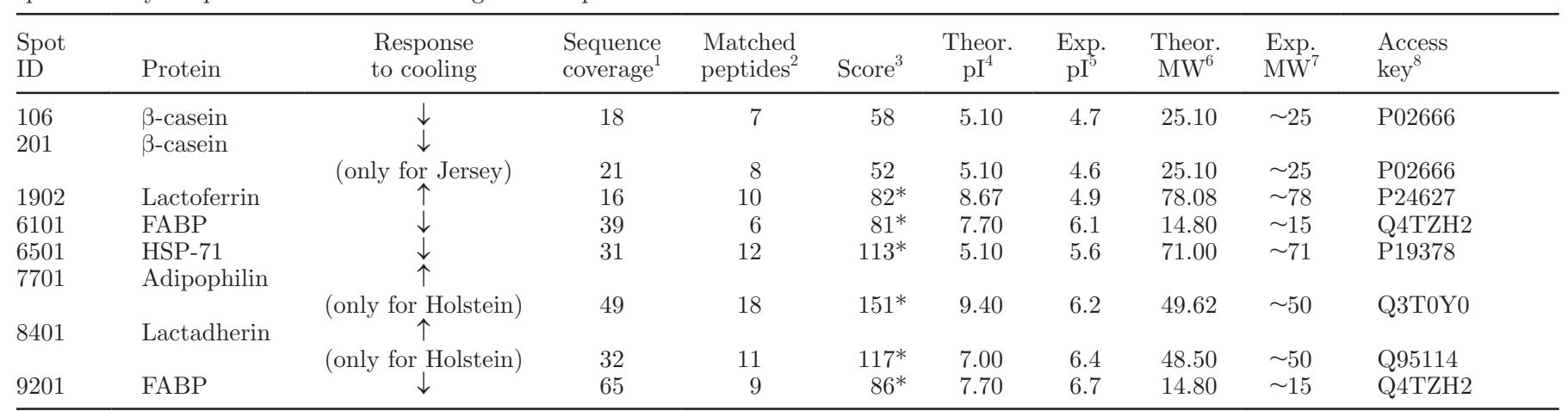

${ }^{1}$ The minimum coverage of the matched peptides in relation to the full-length sequence.

${ }^{2}$ The number of matched peptides in the database search.

${ }^{3}$ Score of the Mascot search. Significant scores $(P<0.05)$ are marked with an asterisk.

${ }^{4}$ Theoretical isoelectric point (pI) of the full-length protein.

${ }^{5}$ Experimental pI of spot.

${ }^{6}$ Theoretical molecular mass (MW) of the full-length protein in kilodaltons.

${ }^{7}$ Experimental molecular mass (MW) of spot in kilodaltons.

${ }^{8}$ Primary accession key in the SWISS-PROT database (http://expasy.org/sprot/).

chosen to enhance the resolution of MFGM proteins on the 2-dimensional gels. Furthermore, XOD with molecular weights of $150 \mathrm{kDa}$ for each of its subunits is most likely too large to enter the IPG strips (Berglund et al., 1996). Both XOD and LPL are known to change their association with the MFGM or their enzyme activities as a function of fresh milk cooling (Bhavadasan and Ganguli, 1980; Ahrné and Bjorck, 1985; Wiking et al., 2003).

\section{CONCLUSIONS}

In conclusion, it was found that not only LPL changes its association to the MFGM upon cooling: the MFGM proteins adipophilin, FABP, and lactadherin, as well as the non-MFGM-related proteins $\beta$-casein, lactoferrin, and HSP-71 were found to migrate between the skim milk and cream phases upon cooling of fresh milk. The stability of the MFGM and its susceptibility to attachment of LPL is expected to depend on this migration of proteins. Migration of membrane components as an effect of temperature has been reviewed by Evers (2004a). The differences between the breeds were not explained by this study and further research on the topics would be necessary to fully understand the changes in protein distribution during milk cooling and storage to elaborate on the relevance and significance for the dairy industry.

\section{ACKNOWLEDGMENTS}

We gratefully acknowledge G. Olivecrona and E. Makoveychuk (Department of Medical Biosciences,
Umeå University, Sweden) for an introduction to the LPL activity analysis and for the substrate used. We also acknowledge the excellent technical assistance of H. S. Møller and K. H. Høirup (Faculty of Agricultural Sciences, Aarhus University, Denmark). This work was financially supported by the DARCOF III program, the Danish Dairy Board, and the Ministry of Food, Agriculture and Fisheries, Denmark.

\section{REFERENCES}

Ahrné, L., and L. Bjorck. 1985. Lipolysis and the distribution of lipase activity in bovine-milk in relation to stage of lactation and time of milking. J. Dairy Res. 52:55-64.

Alder, G. M., B. M. Austen, C. L. Bashford, A. Mehlert, and C. A. Pasternak. 1990. Heat-shock proteins induce pores in membranes. Biosci. Rep. 10:509-518.

Andersen, M. H., L. Berglund, J. T. Rasmussen, and T. E. Petersen 1997. Bovine PAS- $6 / 7$ binds $\alpha(\mathrm{V}) \beta(5)$ integrin and anionic phospholipids through two domains. Biochemistry 36:5441-5446.

Andersen, M. H., H. Graversen, S. N. Fedosov, T. E. Petersen, and J. T. Rasmussen. 2000. Functional analyses of two cellular binding domains of bovine lactadherin. Biochemistry 39:6200-6206.

Berglund, L., J. T. Rasmussen, M. D. Andersen, M. S. Rasmussen, and T. E. Petersen. 1996. Purification of the bovine xanthine oxidoreductase from milk fat globule membranes and cloning of complementary deoxyribonucleic acid. J. Dairy Sci. 79:198-204.

Bhavadasan, M. K., and N. C. Ganguli. 1980. Free and membranebound xanthine oxidase in bovine milk during cooling and heating. J. Dairy Sci. 63:362-367.

Casaroli-Marano, R. P., R. Garcia, E. Vilella, G. Olivecrona, M. Reina, and S. Vilaro. 1998. Binding and intracellular trafficking of lipoprotein lipase and triacylglycerol-rich lipoproteins by liver cells. J. Lipid Res. 39:789-806.

Chirico, W. J., M. G. Waters, and G. Blobel. 1988. 70K heat-shock related proteins stimulate protein translocation into microsomes. Nature 332:805-810.

Cinbas, T., and M. Kilic. 2006. Proteolysis and lipolysis in white cheeses manufactured by two different production methods. Int. J. Food Sci. Technol. 41:530-537. 
Copland, S. D., A. A. Murphy, and B. D. Shur. 2009. The mouse gamete adhesin, SED1, is expressed on the surface of acrosome-intact human sperm. Fertil. Steril. 92:2014-2019.

Davies, D. T., and A. J. R. Law. 1983. Variation in the protein-composition of bovine casein micelles and serum casein in relation to micellar size and milk temperature. J. Dairy Res. 50:67-75.

Deeth, H. C. 2006. Lipoprotein lipase and lipolysis in milk. Int. Dairy J. $16: 555-562$.

Driessen, F. M. 1989. Inactivation of lipases and proteinases (indigenous and bacterial). Pages 71-93 in Bulletin of the International Dairy Federation 238. International Dairy Federation, Brussels, Belgium.

Ensslin, M. A., and B. D. Shur. 2003. Identification of mouse sperm SED1, a bimotif EGF repeat and discoidin-domain protein involved in sperm-egg binding. Cell 114:405-417.

Evers, J. M. 2004a. The milkfat globule membrane-Compositional and structural changes post secretion by the mammary secretory cell. Int. Dairy J. 14:661-674.

Evers, J. M. 2004b. The milkfat globule membrane-Methodologies for measuring milkfat globule (membrane) damage. Int. Dairy J. 14:747-760.

Evers, J. M., R. G. Haverkamp, S. E. Holroyd, G. B. Jameson, D. D. S. Mackenzie, and O. J. McCarthy. 2008. Heterogeneity of milk fat globule membrane structure and composition as observed using fluorescence microscopy techniques. Int. Dairy J. 18:1081-1089.

Fong, B. Y., and C. S. Norris. 2009. Quantification of milk fat globule membrane proteins using selected reaction monitoring mass spectrometry. J. Agric. Food Chem. 57:6021-6028.

Fong, B. Y., C. S. Norris, and A. K. H. MacGibbon. 2007. Protein and lipid composition of bovine milk-fat-globule membrane. Int. Dairy J. $17: 275-288$.

Fox, P. F., and A. L. Kelly. 2006. Indigenous enzymes in milk: Overview and historical aspects - Part 1. Int. Dairy J. 16:500-516.

Graves, E. L. F., A. D. Beaulieu, and J. K. Drackley. 2007. Factors affecting the concentration of sphingomyelin in bovine milk. J. Dairy Sci. 90:706-715.

Hatomi, M., K. Tanigawa, M. Fujihara, J. Ito, S. Yanahira, and K. Ohtsuki. 2000. Characterization of bovine and human lactoferrins as glycyrrhizin-binding proteins and their phosphorylation in vitro by casein kinase II. Biol. Pharm. Bull. 23:1167-1172.

Heid, H. W., M. Schnolzer, and T. W. Keenan. 1996. Adipocyte differentiation-related protein is secreted into milk as a constituent of milk lipid globule membrane. Biochem. J. 320:1025-1030.

Hohe, K. A., P. S. Dimick, and A. Kilara. 1985. Milk lipoprotein-lipase distribution in the major fractions of bovine-milk. J. Dairy Sci. 68:1067-1073.

Humbert, G., M. F. Guingamp, and G. Linden. 1997. Method for the measurement of lipase activity in milk. J. Dairy Res. 64:465469.

Hvarregaard, J., M. H. Andersen, L. Berglund, J. T. Rasmussen, and T. E. Petersen. 1996. Characterization of glycoprotein PAS-6/7 from membranes of bovine milk fat globules. Eur. J. Biochem. 240:628-636.

International Dairy Federation. 1991. Determination of free fatty acids in milk and milk products. International Dairy Federation Bulletin 265. International Dairy Federation, Brussels, Belgium.

Iverius, P. H., and A. M. Ostlundlindqvist. 1976. Lipoprotein-lipase from bovine milk - Isolation procedure, chemical characterization, and molecular-weight analysis. J. Biol. Chem. 251:7791-7795.

Kang, D. H., Y. S. Gho, M. K. Suh, and C. H. Kang. 2002. Highly sensitive and fast protein detection with coomassie brilliant blue in sodium dodecyl sulfate-polyacrylamide gel electrophoresis. Bull. Korean Chem. Soc. 23:1511-1512.

Kvistgaard, A. S., L. T. Pallesen, C. F. Arias, S. Lopez, T. E. Petersen, C. W. Heegaard, and J. T. Rasmussen. 2004. Inhibitory effects of human and bovine milk constituents on rotavirus infections. J. Dairy Sci. 87:4088-4096.

Lametsch, R., and E. Bendixen. 2001. Proteome analysis applied to meat science: Characterizing post mortem changes in porcine muscle. J. Agric. Food Chem. 49:4531-4537.
Larsen, L. B., A. Wedholm-Pallas, H. Lindmark-Mansson, and A. Andren. 2010. Different proteomic profiles of sweet whey and rennet casein obtained after preparation from raw versus heat-treated skimmed milk. Dairy Sci. Technol. 90:641-656

Lopez, C., M. N. Madec, and R. Jimenez-Flores. 2010. Lipid rafts in the bovine milk fat globule membrane revealed by the lateral segregation of phospholipids and heterogeneous distribution of glycoproteins. Food Chem. 120:22-33.

Mather, I. H. 2000. A review and proposed nomenclature for major proteins of the milk-fat globule membrane. J. Dairy Sci. 83:203247.

McSweeney, P. L. H. 2004. Biochemistry of cheese ripening. Int. J. Dairy Technol. 57:127-144.

Newburg, D. S., J. A. Peterson, G. M. Ruiz-Palacios, D. O. Matson, A. L. Morrow, J. Shults, M. D. Guerrero, P. Chaturvedi, S. O. Newburg, C. D. Scallan, M. R. Taylor, R. L. Ceriani, and L. K. Pickering. 1998. Role of human-milk lactadherin in protection against symptomatic rotavirus infection. Lancet 351:1160-1164.

Nilsson-Ehle, P., A. S. Garfinkel, and M. C. Schotz. 1980. Lipolytic enzymes and plasma-lipoprotein metabolism. Annu. Rev. Biochem. 49:667-693.

O'Donnell, R., J. W. Holland, H. C. Deeth, and P. Alewood. 2004. Milk proteomics. Int. Dairy J. 14:1013-1023.

Olivecrona, G., and T. Olivecrona. 1995. Triglyceride lipases and atherosclerosis. Curr. Opin. Lipidol. 6:291-305.

Olivecrona, T., and G. Bengtsson. 1984. Lipases in Milk. Pages 205261 in Lipases. B. Borgström and H. L. Brockman, ed. Elsevier, Amsterdam, the Netherlands.

Olivecrona, T., and G. Olivecrona. 2000. Determination and clinical significance of lipoprotein lipase and hepatic lipase. Pages 479-498 in Handbook of Lipoprotein Testing. N. Rifai, G. Warnick, and M. Dominiczak, ed. AACC Press, Washington, DC.

Osborne, J. C., G. Bengtssonolivecrona, N. S. Lee, and T. Olivecrona. 1985. Studies on inactivation of lipoprotein-lipase - Role of the dimer to monomer dissociation. Biochemistry 24:5606-5611.

Pierce, A., D. Colavizza, M. Benaissa, P. Maes, A. Tartar, J. Montreuil, and G. Spik. 1991. Molecular-cloning and sequence-analysis of bovine lactotransferrin. Eur. J. Biochem. 196:177-184.

Reinhardt, T. A., and J. D. Lippolis. 2006. Bovine milk fat globule membrane proteome. J. Dairy Res. 73:406-416.

Schroeder, F., C. A. Jolly, T. H. Cho, and A. Frolov. 1998. Fatty acid binding protein isoforms: Structure and function. Chem. Phys. Lipids 92:1-25.

Sehayek, E., T. Olivecrona, G. Bengtsson-Olivecrona, I. Vlodavsky, H. Levkovitz, R. Avner, and S. Eisenberg. 1995. Binding to heparansulfate is a major event during catabolism of lipoprotein-lipase by HEPG2 and other cell-cultures. Atherosclerosis 114:1-8.

Senda, M., K. Oka, W. V. Brown, P. K. Qasba, and Y. Furuichi. 1987. Molecular-cloning and sequence of a cDNA coding for bovine lipoprotein-lipase. Proc. Natl. Acad. Sci. USA 84:4369-4373.

Singer, S. J., and G. L. Nicolson. 1972. The fluid mosaic model of structure of cell-membranes. Science 175:720-731.

Spik, G., B. Coddeville, and J. Montreuil. 1988. Comparative study of the primary structures of sero-, lacto- and ovotransferrin glycans from different species. Biochimie 70:1459-1469.

Spitsberg, V. L., E. Matitashvili, and R. C. Gorewit. 1995. Association and coexpression of fatty-acid-binding protein and glycoprotein CD36 in the bovine mammary-gland. Eur. J. Biochem. 230:872878.

Steffensen, C., J. Hermansen, and J. Nielsen. 2004. The effect of milk fat composition on release of xanthine oxidase during cooling. Milchwissenschaft 59:176-179.

Sundheim, G., and G. Bengtsson-Olivecrona. 1985. Lipolysis in milk induced by cooling or by heparin - Comparisons of amount of lipoprotein-lipase in the cream fraction and degree of lipolysis. J. Dairy Sci. 68:589-593.

Sundheim, G., and G. Bengtsson-Olivecrona. 1987. Isolated milk-fat globules as substrate for lipoprotein-lipase - Study of factors relevant to spontaneous lipolysis in milk. J. Dairy Sci. 70:499-506.

Vanderghem, C., C. Blecker, S. Danthine, C. Deroanne, E. Haubruge, F. Guillonneau, E. De Pauw, and F. Francis. 2008. Proteome 
analysis of the bovine milk fat globule: Enhancement of membrane purification. Int. Dairy J. 18:885-893.

Walstra, P., and R. Jenness. 1984. Dairy Chemistry and Physics. J. Wiley and Sons, New York, NY.

Wang, L., and H. E. Randolph. 1978. Activation of lipolysis. I. Distribution of lipase activity in temperature activated milk. J. Dairy Sci. 61:874-880.

Wedholm, A., H. S. Moller, A. Stensballe, H. Lindmark-Mansson, A. H. Karlsson, R. Andersson, A. Andren, and L. B. Larsen. 2008.
Effect of minor milk proteins in chymosin separated whey and casein fractions on cheese yield as determined by proteomics and multivariate data analysis. J. Dairy Sci. 91:3787-3797.

Wiking, L., H. C. Bertram, L. Bjorck, and J. H. Nielsen. 2005. Evaluation of cooling strategies for pumping of milk-Impact of fatty acid composition on free fatty acid levels. J. Dairy Res. 72:476-481.

Wiking, L., L. Bjorck, and J. H. Nielsen. 2003. Influence of feed composition on stability of fat globules during pumping of raw milk. Int. Dairy J. 13:797-803. 